\title{
Hametz, Maura E. and Heidi Schlipphacke, eds. 2018. Sissi’s World: The Empress Elisabeth in Memory and Myth. New York, NY: Bloomsbury Academic. 393 pp.
}

\author{
Reviewed by Christopher Max VanDemark ${ }^{1}$, New York University
}

Scanning the cover of Maura E. Hametz's and Heidi Schlipphacke's Sissi's World: The Empress Elisabeth in Memory and Myth, the prospective reader is confronted with a curious set of images. One, a black-and-white still from Sissi, a 1955 Austrian film directed by Ernst Marischka and starring Romy Schneider as the Empress; the other, a photograph of Ulrike Truger's monument to liminality and ephemerality, Zwang-Flucht-Freiheit ('ConstraintEscape-Freedom'). These twin representations perfectly embody the mnemonic quality of the figure of Sissi, one primarily concerned with the instabilities of the Sissi mythos across time and space. Indeed, Sissi's World is largely disinterested in the Empress as a historical figure and, instead, the authors consider the multifold ways in which consumers of history - tourists, moviegoers, fashion enthusiasts - have processed, assessed, and interpreted representations of the Empress since her death in 1898. In this way, the cover art is well-suited to a volume, “... dedicated to exploring the ways in which the Habsburg Empress is remembered and imagined, embodied and disembodied, recalled, revered, and constructed" (2). Indebted in large part to Walter Benjamin's critique of historicity, the articles featured in the volume examine the Elisabeth myth through the lens of the present, mnemonically, engaging critically with the distortive predilections of recollection and commemoration. In his landmark study on historical revisionism and political misrepresentation in post-Communist Hungary, István Rév enlists similar categories, exploring how history is produced (and reproduced) in a state where the past is constantly remade, contested, and re-appropriated (Retroactive Justice: Prehistory of PostCommunism; Stanford, CA: Stanford UP, 2005). Expanding upon this conceptual framework, Sissi's World surveys the interplay between memory, history, and nostalgia to understand the enduring fascination with the Habsburg Empress and her image, one which to this day continues to resonate across diverse cultures. "Sissi's World," then, has little to do with the Empress herself. As Hametz and Schlipphacke note, it is rather the "... diverse constellation of consumer objects and cultural works that refer, whether directly or indirectly, to the Empress Elisabeth" (24). In this sense, Schneider's Sissi and Truger's sculpture are sites for the production of

${ }^{1}$ cmv352@nyu.edu

(cc) BY

ULIS D-ferle
New articles in this journal are licensed under a Creative Commons Attribution 4.0 International License.

This journal is published by the University Library System of the University of Pittsburgh as part of its D-Scribe Digital Publishing Program and is cosponsored by the University of Pittsburgh Press 
VanDemark, Christopher Max. "Hametz, Maura E. and Heidi Schlipphacke, eds. 2018. Sissi's World: The Empress Elisabeth in Memory and Myth. New York, NY: Bloomsbury Academic. 393 pp." Hungarian Cultural Studies. eJournal of the American Hungarian Educators Association, Volume 12 (2019) DOI: 10.5195/ahea.2019.380

nostalgic ideologies, material representations that recapture and revitalize the ever-tenacious Elisabeth cult.

The articles included in the first part, "Memory," investigate physical representations of the Empress that "... attempt to capture her as an historic figure and then reimagine her place in time and space" (23). In "Encounters: Ulrike Truger, Elisabeth-Zwang-Flucht_Freiheit, 1998/99," Christiane Hertel offers a close examination of Truger's monumental Elisabeth sculpture, untangling the historical threads that inspired the striking marble depiction of the late Empress. It is the sculpture's unique threefold (Dreiansichtigkeit) design that entices the viewer's dialectical engagement with the Sissi myth, both welcoming and confounding sustained reflection on the Empress' life and legacy. This jarring state of in-betweenness and non-linearity complicates simple biographical association and, instead, encourages localized, fragmentary reflection. As Hertel notes, beholders may consider the piece at once a representation of 1990s monumental sculpture, a reference to Elisabeth's life, her assassination or, on some days, to their own experiences (49). In any event, the result is an evocative reproduction of Elisabeth's unstable legacy, her emergence, reemergence, and disappearance in the cultural imaginary and her resistance to linearity and fixedness. Beth Ann Muellner's "The Remains of the Stay: The Corporeal Archive of Empress Elisabeth in the Hofburg" uses nostalgia as a frame for understanding how Vienna's Sissi Museum “... functions as intermediary between personal memory and collective experience..." (54). Proximity, positionality, and scale influence how visitors process the exhibition, a nostalgic space that implicates the body of its primary historical subject and that of the tourist onlooker. Similarly, Judith Szapor and András Lénárt's article, "Sisi Redux: The Empress Elisabeth and Her Cult in Post-Communist Hungary," examines the permanent Sissi exhibition at the Gödöllö Royal Palace Museum as a site for the transmission of a syrupy Habsburg nostalgia, revitalized and renewed after the collapse of Communism in 1989. Cast in hues of sepia, the exhibition pays homage to the late Empress without offering any substantive interpretation or analysis, treating its subjects like mere props in a play (97). As Szapor and Lénárt note, after 1989, Elisabeth's likeness was decontextualized and historically decentered, transformed into an empty vessel for individuals and nations to "project their desires, sympathies, and frustrations" (98). Still today, Hungarian political operatives continue to pour meaning into the empty dress form of the enigmatic Empress, using her image to recast sensitive aspects of Hungarian history. In "A Place for Sissi in Trieste," Maura Hametz and Borut Klabjan transport the reader to the Adriatic, the center of Habsburg maritime activity in the nineteenthand early twentieth-century. As in neighboring Hungary, the mutable figure of Elisabetta became a "... prism with facets refracting light that appears, depending on the perspective, in various colors of competing nationalist currents and political agendas" (104). Tracing the turbulent history of a statue commissioned after the Empress' death, Hametz and Klabjan connect Elisabeth's presence (and absence) in Trieste to the city's divisive past, a site of inter-ethnic discord, political persecution, and conflict since the nineteenth-century.

The final three articles featured in the first part of the volume explore the interplay between reality and fantasy, accessibility and retreat. Olivia Gruber Florek's "Empress Elisabeth and the Painting of Modern Life" offers a close examination of Franz Xaver Winterhalter's famous 1865 state portrait of Empress Elisabeth. Far from a one-dimensional object of princely self-projection, the Winterhalter portrait invites the viewer to reconsider the traditional tenets of imperial portraiture by blurring the boundaries between elite and demimonde sensibilities. The portrait toys with established notions of aristocratic propriety and femininity, complicating our understanding of nineteenth-century queens as "... chaste symbols of retrograde institutions" 
VanDemark, Christopher Max. "Hametz, Maura E. and Heidi Schlipphacke, eds. 2018. Sissi's World: The Empress Elisabeth in Memory and Myth. New York, NY: Bloomsbury Academic. 393 pp." Hungarian Cultural Studies. eJournal of the American Hungarian Educators Association, Volume 12 (2019) DOI: 10.5195/ahea.2019.380

(152). In this way, Elisabeth temporarily shed her role as imperial escort and became the queen of the ball (147). In "Karl Lagerfeld and the Elisabeth Myth," Carolin Maikler considers two fictional depictions of the Empress to unravel the Sissi myth's relationship to the modern Zeitgeist. In both the photography book and the short film, fantasy, sexuality, and desire collide, recasting the Empress as a timeless beauty, an ahistorical, yet distinctly modern manifestation of Lagerfeld's own unique Weltanschauung. In "Sissi, the Chinese Princess: A Timely and Versatile Post-Mao Icon," Fei-Hsien Wang and Ke-chin Hsia investigate the popularity of the fictional Sissi trope in modern China. Distance is a crucial category for Wang and Hsia, as Chinese fans constructed a fanciful, unhistorical Princess Xixi built on the imperial splendor depicted in the Sissi film trilogy. Engendering a kind of Old World, fairytale charm, Princess Xixi could be consumed and enjoyed "... without feeling politically or ideologically guilty" (188). As in Szapor and Lénárt's article, Princess Xixi became a “... de-contextualized fantasy" onto which dreams, desires, and aspirations of many kinds can be liberally projected and then manipulated for different purposes (209). Thus, Elisabeth - restyled Princess Xixi - has been transformed and indigenized, fully embodying the contradictions of a post-Mao consumer society.

The second part of the volume, "Myth," features a cluster of thematically overlapping articles that study the Empress through the lens of "reconstructed visions," which serve to reconfigure Sissi for a modern audience (23). In "Melancholy Empress: Queering Empire in Ernst Marischka's Sissi Films" and "Sisi: A Double Reflection on a 'Queer Icon," Heidi Schlipphacke and Susanne Hochreiter offer a queer reading of the Empress that gestures towards themes of (dis)identification, displacement, and performativity. Subverting conventional interpretations of Marischka's iconic Sissi trilogy, Schlipphacke suggests that, when considered through a queer lens, the films reflect an "... anxiety about fixed locations and stable notions of home" (217). Spectators have traditionally associated the Sissi trilogy with the Heimatfilm genre, an escapist, fanciful mode of filmmaking popularized after World War II. Schlipphacke challenges this designation, arguing that the films dramatize postwar feelings of displacement and restlessness pervasive in 1950s Germany and Austria. Likewise, Hochreiter's article employs the concept of "queer temporalities" to reimagine Sissi as a "queer icon." In queering the Sissi discourse, Hochreiter accesses categories of analysis - parody and allegory - that illuminate the continued fascination with the late Austrian Empress both within and outside queer circles. Borrowing from postcolonial paradigms, Anita McChesney demonstrates how the semi-factual, semi-fictional representations of the Empress featured in Lilian Faschinger's Wiener Passion expose both an idealized conception of national selfhood and the "... blind spots inherent in images used to imagine and reify cultural identity" (278). McChesney suggests that the Empress, like the Austria she embodies, is a malleable cluster of images and the nation "... an imagined community whose identity is constructed by layers of myths" (299). Elizabeth Black's "Cocteau's Queen: Sissi Between Legend, Spectacle, and History in L'Aigle á deux têtes" similarly blurs the boundaries between fantasy and truth, closely examining Jean Cocteau's play and subsequent film-adaption to demonstrate how royal spectacle, classical tragedy, and cinematic spectacle interface with historical reality. Kate Thomas' "Fat, Thin, Sad: Victoria, Sissi, Diana and the Fate of Wax Queens" contributes to a bourgeoning scholarly interest in embodied intersubjectivities and fat studies, an analytic approach that she closely aligns with queer studies. Through this lens, Thomas explores the imperial female body as an interchangeable, mutable entity, one which transgresses space and time, despite “... Victoria's increasing girth, Sissi's disciplined emaciation, and Diana's bulimic vacillation." As Thomas put 
VanDemark, Christopher Max. "Hametz, Maura E. and Heidi Schlipphacke, eds. 2018. Sissi's World: The Empress Elisabeth in Memory and Myth. New York, NY: Bloomsbury Academic. 393 pp." Hungarian Cultural Studies. eJournal of the American Hungarian Educators Association, Volume 12 (2019) DOI: 10.5195/ahea.2019.380

it, "[they] are all defined by the space they occupy, and they are all simultaneously specularized and spectralized, at once material and immaterial" (350). Susanne Kelly's article, "Sisi in the Museum: Exhibits in Vienna and the US," examines Sissi's peculiar presence in two recent exhibitions, one in Vienna and the other in the United States. In both cases, the Empress played a largely ancillary role, appearing almost exclusively in the marketing campaign surrounding the exhibitions. Kelly argues that these public-facing representations largely undermine the “... exhibits' focus on the historical gaze" (358); instead, the Empresses' likeness, used to sell tickets and merchandise, disrupts and reorients visitors' perceptions, appealing to the public's fascination with the romantic and nostalgic.

Dedicated to "... women everywhere who, like Sissi, wish to shape their own images and then leave them behind," Sissi's World probes the relationship between past and present, between historical discourse and personal experience, and the ways in which this interchange produces nostalgic narratives. Integrative in its approach and global in its perspective, this volume is chock full of fascinating articles that will engage readers across disciplines. 